
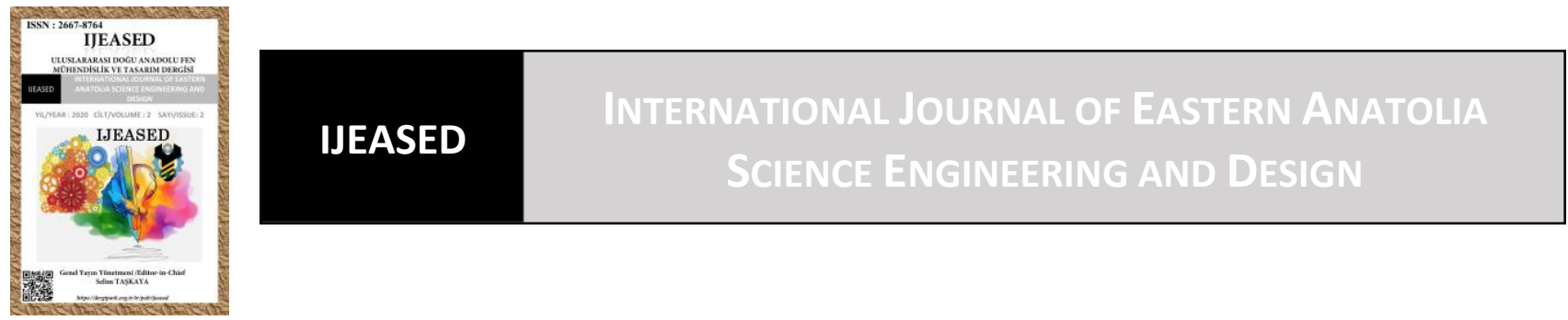

\author{
Uluslararası Doğu Anadolu Fen Mühendislik ve Tasarım Dergisi \\ ISSN: 2667-8764, 2(2), 348-369, 2020 \\ https://dergipark.org.tr/tr/pub/ijeased
}

Araştırma Makalesi / Research Article

Doi: $\underline{10.47898 / \text { ijeased.801324 }}$

\title{
Priming Uygulamalarının Farklı Gelişim Dönemlerindeki Patlıcan Tohumlarının Canlılık ve Kalitesi Üzerine Etkisi
}

\author{
Yasemin ÇELİK ${ }^{1}$, Burcu Begüm KENANOĞLU ${ }^{2 *}$ \\ ${ }^{1}$ Uşak Üniversitesi, Fen Bilimleri Enstitüsü, Uşak, 64200, Türkiye. \\ ${ }^{2}$ Uşak Üniversitesi, Ziraat Fakültesi, Bahçe Bitkileri Bölümü, Uşak, 64200, Türkiye.
}

\begin{tabular}{|c|c|c|}
\hline Yazar Kimliği / Author ID (ORCID Number) & Makale Süreci / Article & rocess \\
\hline $\begin{array}{l}\text { Sorumlu Yazar / Corresponding author: } \\
\text { burcu.kenanoglu@ usak.edu.tr } \\
\text { iD https://orcid.org/0000-0003-2653-5399 ，Y. Çelik } \\
\text { iD https://orcid.org/0000-0001-5307-5194 ，B.B. Kenanoğlu }\end{array}$ & $\begin{array}{l}\text { Geliş Tarihi / Received Date : } \\
\text { Revizyon Tarihi / Revision Date: } \\
\text { Kabul Tarihi / Accepted Date : } \\
\text { Yayım Tarihi / Published Date : }\end{array}$ & $\begin{array}{l}28.09 .2020 \\
02.11 .2020 \\
08.11 .2020 \\
15.12 .2020\end{array}$ \\
\hline
\end{tabular}

Alıntı / Cite : Çelik, Y., Kenanoğlu, B.B. (2020). Priming Uygulamalarının Farklı Gelişim Dönemlerindeki Patlıcan Tohumlarının Canlılık Ve Kalitesi Üzerine Etkisi, Uluslararası Doğu Anadolu Fen Mühendislik ve Tasarım Dergisi, 2(2), 348-369.

\begin{abstract}
Özet
$\mathrm{Bu}$ araştırmada, Kemer 27 patlıcan çeşidine ait tohumların hidropriming (HP), osmopriming (OP) ve termopriming (TP) uygulamalarının tohum kalitesi üzerine etkileri araştırılmıştır. Kemer 27 (K) çeşidinin farklı olgunluk seviyelerinde hasat edilen (çiçeklenmeden sonraki 50,55,60,70,80 ve 90. gün) tohumları 35 ve $15^{\circ} \mathrm{C}$ 'de 8 saat $(4: 4$ sa/karanlık-aydınlık koşulda) süre boyunca, \%10'luk PEG-6000 ile OP, 35 ve $15{ }^{0} \mathrm{C}^{\prime}$ de 8 saat (4:4 sa/karanlık-aydınlık koşulda) sürede saf su ile HP ve $50^{\circ} \mathrm{C}^{\prime}$ de 2 farklı sürede (15 ve 30 dakika) su banyosunda TP işlemleri uygulanmıştır. Tüm kontrol ve uygulama gruplarında tohum nem miktarlarındaki değişim belirlenmiştir. Denemeler sonucunda, patlıcan tohumlarının priming uygulamaları ile canlılık (ortalama çimlenme oranı ve süresi, kök-sürgün uzunlukları, nem değişimleri) kriterleri değerlendirilmiştir. Genel olarak incelenen parametrelere göre priming olumlu etkisi tohumların olgunluğu ile ilişkili bulunmuştur. Yapılan Duncan testi sonuçlarına göre toplam ve normal çimlenme oranları (\%) ile nem miktarları (\%) açısından hasat zamanı, priming ve interkasiyonları arasındaki farklılığın istatistiki olarak değişken düzeylerde önemli $(\mathrm{p} \leq 0.05,0.01)$ olduğu belirlenmiştir. Kök ve sürgün uzunlukları (mm) bakımından ise hasat zamanları arasındaki farklılık istatistiksel olarak anlamlı bulunmuştur $(\mathrm{p}<0.01)$. Bu çalışma ile patlıcan tohumlarında kullanılan özellikle TP uygulaması diğer priming metotlarına göre çimlenme performansı üzerine daha etkili olmuştur. Kimyasal madde olmadan yapılan bu teknik girdi masraflarını da azalttığı için özellikle organik üretimde kullanılacak tohumlar için alternatif bir uygulama olarak önerilebilir.
\end{abstract}

Anahtar Kelimeler: Solanum melongena L., Hidropriming, Ozmopriming, Termopriming, Çimlenme performansı. 


\title{
The Effect of Priming Treatments on Vitality and Quality of Eggplant Seeds in Different Maturity Periods
}

\begin{abstract}
In this research, the effects of hidropriming (HP), ozmopriming (OP) and thermopriming (TP) treatments on seed quality in Kemer 27 eggplant variety seeds were investigated. Eggplant cv..Kemer 27 (K) seeds which harvested at different maturity levels (50,55,60,70,80 and 90. days after flowering) were subjected to OP treatments at 15 and 35 OC for 8 hours (4:4 / in the dark-light condition) with 10\% PEG-6000 solution, HP treatments at 15 and 35 OC (4:4 / darklight condition) for 8 hours with distilled water and TP treatments were applied in water bath for two different times (15 and 30 minutes) at $50{ }^{\circ} \mathrm{C}$. Change of seed moisture levels were determined in control and priming groups in all cultivars. At the end of the experiments; all priming treatments of eggplant seeds were evaluated on the basis of viability (mean germination rate and time, seedling root-shoot length, changes of moisture). Generally, when the analyzed parameters were evaluated, it was seen that the priming positive effect was related to the maturity of the seeds. According to Duncan test results, it was determined that the difference between harvest time, priming and interactions in terms of total and normal germination rates (\%) and moisture content (\%) was statistically significant $(p \leq 0.05,0.01)$ at varying levels. Regarding to the root and shoot lengths $(\mathrm{mm})$, the difference between harvest times was found to be statistically significant ( $p<0.01$ ). With this study, especially TP treatment used in eggplant seeds was more effective on germination performance than other priming methods. This technique, which is made without chemicals, can be applied especially in organic seeds as it also reduces input costs.
\end{abstract}

Key words: Solanum melongena L, Hydropriming, Osmopriming, Thermopriming, Germination performance.

\section{Giriş}

Patlıcan, Solanaceae familyasına ait bir tür olup, anavatanı Hindistan olarak bilinmektedir. Dünya ve Türkiye'de sebze yetiştiriciliği açısından patlıcan (Solanum melongena L.) en çok üretilen, tüketilen ve ekonomik açıdan en yüksek olan türler arasında yer almaktadır. Birleşmiş Milletler Gıda ve Tarım Örgütü verilerine göre, 2018 yılı dünya patlıcan üretimi 29 milyon tondur (FAO, 2018). İstatistiklere göre; ülkemizde 2019 y1lında 30 milyon ton sebze üretimi yapılırken, patlıcan üretimi 822659 ton olarak gerçekleşmiştir (TÜİK, 2019). Patlıcan Solanaceae sebzeleri arasında en termofilik olandır. Bitkisel gelişim, büyüme ve verim için gece en az $15{ }^{0} \mathrm{C}$ ve gündüz 23-25 ${ }^{\circ} \mathrm{C}$ sıcaklıklar gereklidir. Patlıcanın düşük gece sıcaklıklarına toleransı düşüktür. Düşük verim, bozulmuş polen gelişimi ve canlılı̆̆ı, anormal meyve renk gelişimi ve tohumsuz meyve oluşumu olmak üzere birçok anormaliteler görülmektedir (Karapanos ve ark., 2008). Meyve olgunluğunu etkileyen faktörler; ana bitkinin gelişim durumu, ekolojik ve fizyolojik faktörler olarak üç farklı başlık altında değerlendirilmektedir. Meyvenin gelişim ve olgunlaşması için ekolojik olarak öncelikle 1şık, sıcaklık, bitkinin beslenmesi gibi çevre faktörlerinin yanında bazı kültürel işlemler de oldukça önemlidir. Tohum olgunluğu incelendiğinde ise, iki önemli olgunluk kavramı ile karşılaşılır. Bu kavramlar fizyolojik ve hasat olgunluğudur. Fizyolojik olgunluk, tohuma taşınan maksimum kuru madde birikimi ile ilişkili olup tohumun yüksek kaliteye ulaştığı en uygun hasat 
zamanı kriteridir. Bu dönemin belirlenmesi tohum canlılığının yüksek olması ve tohum kayıplarının azalması bakımından önemlidir. Hasat olgunluğu ise, tohumun depolanması için uygun olduğu gelişim dönemidir. Patlıcan meyvelerinin hasadı için en uygun dönem ve tohumun ekstraksiyonu için ideal dinlenme süresinin belirlemesinin amaçlandığı bir çalışmada; meyveler, polinasyondan sonra 49, 56, 63, 70 ve 77. günlerde toplanmış ve her dönemde hasat edilen meyvelerin tohumları, hasattan hemen sonra ya da hasat sonrası bir haftalık dinlenme periyodundan sonra mekanik ekstraksiyon yapılmıştır. Tohumların fizyolojik kalitesi için çimlenme yüzdesi, çimlenme ve çıkış hız endeksleri ve elektriksel iletkenlik testleri yapılmıştır. Tohumların çimlenme ve canlılık sonuçları bakımından meyve hasadı için en uygun sürenin 70 . gün olduğu belirlenmiştir ve tohumların hasattan hemen sonra çıkarılması uygun bulunmuştur (Martins ve ark., 2012). Yapılan çalışmalarda genel olarak; patlıcan tohum üretimi için (Solanum melongena L.) meyveler antesisden yaklaşık 50-60 gün sonra çeşit, iklim ve yetiştirme koşullarına bağlı olarak tam olgunluk döneminde hasat edilmesi önerilmektedir (Chen, 2001; Demir, 2002; Yogeesha, 2008). Ham meyvelerden ekstrakte edilen tohumlar ya çok düşük düzeyde yada hiç çimlenememektedirler. Ayrıca meyve gelişimi ve olgunlaşması sırasında bitkideki meyveler arasında rekabet olması tohum boyutunun azalmasına neden olmaktadır (Passam, 2001). Patlıcan klimakterik bir tür olamasına rağmen, hasat sonrası meyvelerde tohumlar olgunlaşmaya devam edebilmekte ve bu durum çimlenmeyi uyarmaktadır (Passam, 2010). Bazı bitki türleri için tohum maksimum fizyolojik kalite ile maksimum kuru ağırlığa aynı anda ulaşırken, bazı türler için ise öncesi yada sonrası dönemde gerçekleşmektedir. Maksimum kaliteye ulaşıldığı zaman tohumların fizyolojik kalitesinde kademeli azalma teşvik edilmekte ve fizyolojik olgunluktan itibaren, tohum pratik olarak ana bitkiden ayrı olup foto-asimile edilmiş bileşiklerin alımını yapamamaktadır (Demir ve Ellis, 1992).

Priming, birçok türde tohum kalitesini artırmak, çimlenmeyi ve depolama performansını iyileştirmek için kullanılan bir tekniktir (McDonald, 2000). Tohumların, çimlenme öncesi metabolizmanın aktif hale getirilerek tohumdan kökçüğün çıkmasına izin verilmeden bir solüsyon içerisinde nemlendirilmesidir. Priming uygulamasının faydaları; nükleik asitlerin onarımı ve oluşumu, protein sentezinin artması ile hem mitokondrinin hem de hücre zarların onarımı olarak ifade edilmektedir (McDonald, 2000). Ayrıca, priming uygulamaları ile tohumlarda antioksidan mekanizması yenilenmektedir. Bununla birlikte, priming tekniği ile iyileştirilmiş tohumların çimlenmesinin ardındaki fizyolojik nedenler ve biyokimyasal değişiklikler halen belirsizdir. Tohum canlılığını iyileştirmek için kullanılan priming tekniği ile türe göre değişen kritik nem kapsamı 
Çelik, Y., Kenanoğlu, B.B., Uluslararası Doğu Anadolu Fen Mühendislik ve Tasarım Dergisi / International Journal of Eastern Anatolia Science Engineering and Design (IJEASED)

(2020) 2(2):348-369

yükselmektedir. $\mathrm{Bu}$ sayede uzun periyotlarda ve aerobik koşullarda, canlılıkta iyileşme sağlanmaktadır. Örneğin kritik nem kapsamı; marulda \%15 (Ibrahim ve Roberts, 1983), soğanda \%18 (Ward ve Powell, 1983), buğdayda \%28- 30 (Petruzelli, 1986) ve bezelyede \%34-38 (Sivritepe ve Eriş, 2000) olarak belirlenmiştir. Bu yöntemlerden en yaygın olanlarından biri de ozmopriming tekniğidir. Ozmopriming uygulamalarında genellikle polietilen glikol (PEG), mannitol, gliserol, sükroz gibi ozmotik maddeler kullanılır (Parera ve Cantliffe, 1994; Elkoca ve ark., 2006). Genellikle araştırmalarda, tohum fizyolojisini etkileyen yüksek molekül ağırlığına sahip organik bileşik olan PEG kullanılmaktadır (Sivritepe, 1999). Ancak PEG uygulamasının en büyük dezavantajı kullanılan konsantrasyondaki artışa bağlı olarak çözelti içerisinde oksijen çözünürlüğündeki yetersizliktir (Mexal ve ark., 1975). Örneğin, PEG moleküllerinin tohuma girememesi ile tohum ve çevresinin su potansiyeli dengeye geldiğinde tohumun su alımına devam etmeyeceği öne sürülmüştür (Mehra ve ark., 2003).

Hidropriming; tohumlar için uygun sıcaklıklarda ve belli sürelerde su emdirilmesi olayıdır. $\mathrm{Bu}$ teknikte kimyasal madde kullanılmadığı için hem tohumlarda uygulama süresi boyunca kimyasal madde birikimi hem de çevreye zararlı herhangi bir atık ortaya çıkmamaktadır. Ancak bu teknikte bazen hızı su alımı ile tohum dokuları zarar görebilmekte ve su alım zararı meydana gelebilmektedir (McDonald, 2000). Hidropriming, ozmopriming ve giberellik asit yöntemlerinin kullanıldığı bir araştırmada; soğan tohumlarında anormal kök gelişimi engellenerek, özellikle hidropriming uygulamasıyla çimlenme oranı ve çimlenme yüzdesi artmıştır (Tajbakhsh ve ark., 2004). Polietilen glikol (\%20, 25, 29, 32.4, 35 ve 40'l1k PEG-6000 ile 4, 8, 12, 16, 20, 24, 48 ve 96 saat sürelerde) ile yapılan bir çalışmada; ozmopriming uygulamalarının domates, biber, patlıcan ve karnabahar gibi türlerin tohumlarında canlılık ve güç üzerindeki etkiler incelenmiştir. Priming uygulamalarının sonucunda; \%35 ve 40’lık PEG-6000 çözeltileri ile yapılan uygulamaların dışında kontrole göre canlılık ve güç bakımından olumlu sonuçlar alınmıştır. \%29'luk PEG çözeltileri ile 48 saat uygulanan domates tohumlarında; \%32.4'lük PEG çözeltileri ile 48 saat uygulanan biber ve karnabahar tohumlarında, \%32.4'lük PEG çözeltileri ile 48 ve 96 saat uygulama gören patlıcan tohumlarında en iyi sonuçlar belirlenmiştir (Saxena ve Singh, 1987). Birçok çalışmada, patlıcan tohumları için, saf su, PEG ve $\mathrm{KNO}_{3}$ kullanılarak, 0-1.6 $\mathrm{MPa}$ arasında, 15 ve $20{ }^{\circ} \mathrm{C}$ 'de 96 saate kadar çeşitli priming yöntemleri test edilmiştir (Fanan ve Novembre, 2007; Nascimento, 2005; Nascimento ve Lima, 2008; Trigo ve Trigo, 1999). Sharmaa ve ark., (2013) yapmış oldukları bir çalışmada, tohum priming işlemlerinin bamya tohum çimlenmesi, ortalama çimlenme süresi, fide 
performansı, canlılık indeksi ile biyokimyasal parametreler, tohum elektriksel iletkenlik değeri, lipid peroksidasyon, dehidrogenaz aktivitesi, antioksidan enzimler gibi bazı fizyolojik özellikler üzerindeki etkileri incelemişlerdir. Tohumları hidropriming, osmopriming, halopriming ile birlikte farklı priming kombinasyonları ile katı matriks priming işlemine tabi tutmuşlardır. 12 saat boyunca hidropriming ve kalsiyum alüminyum silikat ile 24 saat boyunca matriks priming yapılarak bamyada tohum çimlenmesi, fide gücü, ortalama çimlenme süresi ve pazarlanabilir meyve verimi önemli ölçüde artarken, basit, ekonomik ve güvenli olan hidroprimingin kontrole kıyasla meyve verimini \% 55'e kadar arttırmada etkili olabileceğini öne sürmüşlerdir.

Termopriming tekniğinde ise tohumlar, karanlık ortamda yüksek sıcaklıktaki oksijence zenginleştirilen saf su içerisinde belli sürelerde tutulur. Tohum çimlenme performansı dış ortam sıcaklık uygulamaları ile değişmektedir. Birçok tür ve çeşit için tohumların çimlenme sıcaklıkları mevcuttur. Ekim öncesi yapılan düşük ya da yüksek sıcaklık uygulamaları ile normal ya da toplam çimlenme oranları olumlu etkilenmektedir (Hardegree, 1996; Min ve Seo, 1999). Termopriming uygulamaları hem tohum çimlenmesi ve fide çıkışını olumlu etkilemekte hem de bitki büyümesi ve gelişmesine yardımcı olmaktadır. Ayrıca enzim aktivitesi, bitki büyümesi ve metabolizması üzerine olumlu etkileri olduğu belirlenmiştir. Havuç tohumunun çimlenmesinde yüksek sıcaklıkların olumsuz etkilerini değerlendirmek ve yüksek sıcaklıklarda çimlenme üzerine priming işleminin faydalarını bulma amacıyla yapılan çalışma iki farklı aşamada gerçekleşmiştir. İlk olarak, Brasília havuç tohumları, $35{ }^{\circ} \mathrm{C}$ 'de $24,48,72$ ve 96 saatlik farklı sürelerle termopriming işlemine tabi tutulmuş ardından $20{ }^{\circ} \mathrm{C}$ 'ye aktarmışlardır. Tohumlar ayrıca $20{ }^{\circ} \mathrm{C}$ (optimum) ve $35{ }^{\circ} \mathrm{C}$ (maksimum) sabit sıcaklıklarda priming işlemine tabi tutmuşlardır. İkinci olarak tohumlar 1şık altında, 72 saat boyunca, $15{ }^{\circ} \mathrm{C}$ 'de, havalandırılmış PEG 6000 (\% 30) çözeltisi içinde priming işlemi gerçekleştirilmiştir. Tohumlar daha sonra 20 ve $35^{\circ} \mathrm{C}$ 'de çimlendirilmiştir. Sabit yüksek sıcaklıklar $\left(35^{\circ} \mathrm{C}\right)$ toplam çimlenmeyi azaltırken $35^{\circ} \mathrm{C}$ 'de uzun süre priming işlemine tabi tutulan tohumlar, $20^{\circ} \mathrm{C}^{\prime}$ ye aktarıldıklarında daha düşük bir çimlenme performansı belirlenmiştir. Bununla birlikte, priming işlemine tabi tutulmuş tohumların, olumsuz $\left(35{ }^{\circ} \mathrm{C}\right)$ koşullarda daha yüksek çimlenmeye sahip olduğunu gözlemlemişlerdir. Termopriming uygulamasının, özellikle yaz aylarında tarlada havuç tohum performansını ve tek tip fide oluşumunu iyileştirmek için önemli bir araç olarak kullanılabilir olduğu sonucuna varmışlardır (Nascimento ve Pereira, 2007). Sani ve Jodaeian (2015) yaptıkları çalışmada soya fasulyesi tohumlarının çimlenmesi üzerine farklı zaman aralıklarında (kontrol, 5 ve 10 dakika) uygulanan termopriming etkisinin belirlenmesini 
Çelik, Y., Kenanoğlu, B.B., Uluslararası Doğu Anadolu Fen Mühendislik ve Tasarım Dergisi / International Journal of Eastern Anatolia Science Engineering and Design (IJEASED)

(2020) 2(2):348-369

amaçlamışlardır. Sonuçlara göre termopriming uygulamasının çimlenme yüzdesi, fide kuru ağırlı̆̆ ve fide canlılı̆̆ üzerindeki etkisinin önemli olduğu sonucuna ulaşmışlardır. Sonuçlarında en yüksek çimlenme yüzdesinin (\% 77), en yüksek fide kuru ağırlığının (1.39 g) ve en iyi fide kuvvetinin (107.03) 10 dakikalık termopriming ile elde edildiğini ortaya koymuşlardır.

Bu çalışmada, Kemer 27 patlıcan çeşidine ait tohumlara farklı süre ve sıcaklıklarda ozmo, hidro ve termo priming uygulamaları yapılarak, tohum canlılığının (normal çimlenme oranı ve çimlenme hızı, fide sürgün ve kök uzunlukları) nasıl etkilendiğini ortaya koymak amaçlanmıştır.

\section{Materyal ve Metot}

Bu araştırma 2019-2020 yıllarında Uşak Üniversitesi Ziraat Fakültesine ait araştırma laboratuvar ve uygulama alanında yürütülmüştür.

\subsection{Materyal:}

$\mathrm{Bu}$ araştırmada, bitkisel materyal olarak Fitalya fideden temin edilen Kemer 27 çeşidi patlican tohumları kullanılmıştır. Tohumlar hasatlardan sonra denemelerde kullanılıncaya kadar hermetik olarak kapatılmış cam kavanozlarda ve buzdolabında $4^{\circ} \mathrm{C}$ 'de muhafaza edilmişstir.

\subsection{Yöntem:}

\subsubsection{Tohum Hasadı (Çiçeklenmeden Sonraki Gün Sayısına Göre):}

Nisan 2019'da dikim yapılmış, çevre koşullarına bağlı olarak 30-90 arası çiçek etiketlenmiştir. Çiçeklenme sonrası 50,55,60,70,80 ve 90. günlerde etiketli çiçeklerden ise 15-25 adet meyve tohum amacı ile hasat edilmiştir. Daha sonra hemen hasat (bekletme işlemi yapılmamış) edilen meyvelerden fermantasyon (su) yöntemi ile tohumlar elde edilmiştir.

\subsubsection{Tohum Partilerinin Baslangıç Canlılıkları Ve Nem Kapsamlarının Belirlenmesi}

\subsubsection{Nem Tayini(\%):}

Her partinin tohum nemi, 1g'lık 2 tekerrürlü örnekler ile başlangıç ağırlıkları tartıldıktan sonra $130^{\circ} \mathrm{C}$ 'de 1 saat bekletilmiştir (ISTA, 1999). Ardından tohumlar fırından çıkarıldıktan sonra soğuması için fırın kaplarının ağızları kapalı şekilde desikatörde yarım saat bekletilerek, son 
ağırlıkları tartılmış ve başlangıç nem miktarları (\%) saptanmıştır. Nem tayini başlangıç nemi ve tüm uygulamalar sonucunda yapılmış ve uygulamalar arasındaki nem değişimi gözlemlenmiştir.

Nem miktarı $(\%)=$ BTA-STA $\times 100$

$$
\text { BTA }
$$

BTA: Baslangıç tohum ağıllı̆̆

STA: Son tohum ağırlı̆̆ı

\subsubsection{2.Çimlendirme Testi (\%):}

Çimlendirme testi için her tohum partisi 3 tekerrür x 25 tohum ile petrilerde $25^{\circ} \mathrm{C}$ 'de 14 gün süre ile devam etmiştir (ISTA, 1999). Çimlenme kriteri olarak 2mm'lik kökçük çıkısı esas alınarak, sayımlar her gün yapılmıştır. Çimlendirme denemesinin sonunda toplam (TÇ) ve normal (NÇ) çimlenme oranları (\%) belirlenmiştir. Çimlendirme testi sonunda fidelerin kök (KU) ve sürgün (SU) uzunluk (mm) ölçümleri yapılmıştır.

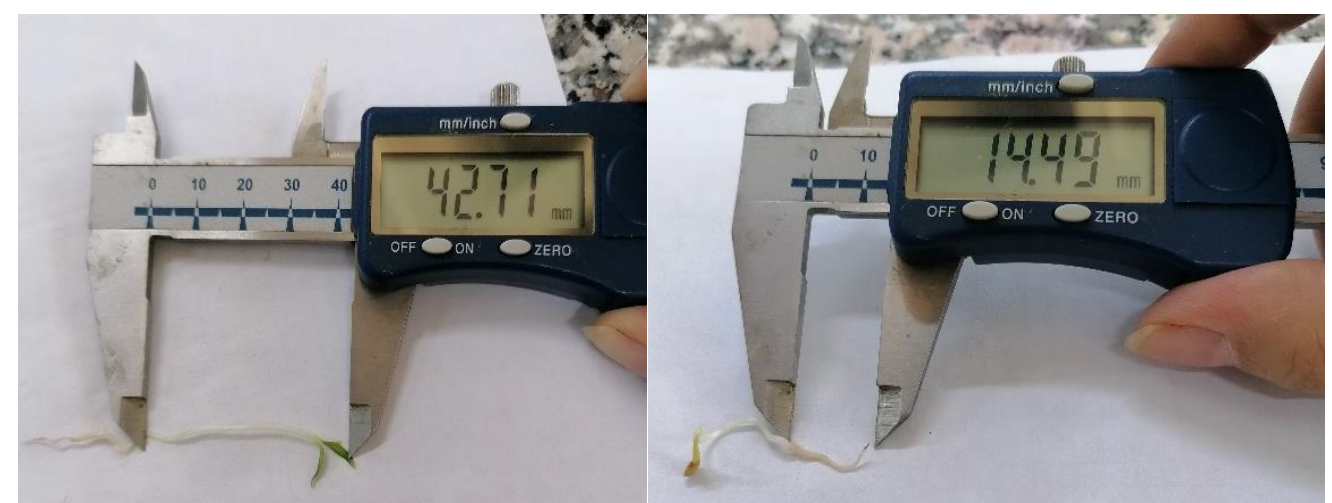

Şekil 1. Kemer 27 patlıcan çeşidinin sürgün (sol taraf) ve kök (sağ taraf) uzunluk ölçümü

\subsubsection{Ortalama Çimlenme Zamanı (gün):}

Çimlendirme denemesi sırasında yapılan günlük sayımlar kullanılarak aşağıdaki formül ile hesaplanmıştır.

$$
\mathrm{OÇZ}=\frac{\Sigma \mathrm{n} \cdot \mathrm{D}}{\Sigma \mathrm{n}}
$$

Formülde; OÇZ: Ortalama çimlenme zamanı
n: D. günde çimlenen tohum sayısı
D: Çimlenme başlangıcından itibaren geçen günü ifade etmektedir 
Çelik, Y., Kenanoğlu, B.B., Uluslararası Doğu Anadolu Fen Mühendislik ve Tasarım Dergisi / International Journal of Eastern Anatolia Science Engineering and Design (IJEASED)

(2020) 2(2):348-369

\subsection{Priming Uygulamaları}

\section{Hidropriming:}

Farklı olgunluk dönemlerine göre keselenen tohumlar saf su içeren küvetlere yerleştirilen tel üzerine dizilmiştir. Uygulama $35^{\circ} \mathrm{C}$ ve $15^{\circ} \mathrm{C}$ etüvlerde 8 saat fotoperiyot (4saat aydınlık, 4saat karanlık) ayarlanarak iki farklı uygulama gerçekleştirilmiştir. İlk uygulamada tohumlar $35^{\circ} \mathrm{C}^{\prime} \mathrm{de}$ 8saat (4saat aydınlık, 4saat karanlık) etüv de bekletilip çimlenme testi için petrilere aktarılmıştır. İkinci uygulamada ise tohumlar $15^{\circ} \mathrm{C}$ 'de 8 saat (4saat aydınlık, 4saat karanlık) etüv de bekletilip çimlenme testi için petrilere aktarılmıştır (Fanan ve Novembre, 2007; Nascimento, 2005; Nascimento ve Lima, 2008; Trigo ve Trigo, 1999).

\section{Ozmopriming:}

Farklı olgunluk dönemlerine göre keselenen tohumlar, PEG çözeltisi (\%10’luk) içeren küvetlere yerleştirilen tel üzerine dizilmiştir. Uygulama $35^{\circ} \mathrm{C}$ ve $15^{\circ} \mathrm{C}$ etüvlerde 8 saat fotoperiyot (4saat aydınlık, 4saat karanlık) olmak üzere iki farklı uygulama gerçekleştirilmiştir. İlk uygulamada tohumlar $35^{\circ} \mathrm{C}$ 'de 8saat (4saat aydınlık, 4saat karanlık) etüv de bekletilip çimlenme testi için petrilere aktarılmıştır. İkinci uygulamada ise tohumlar $15^{\circ} \mathrm{C}$ 'de 8 saat (4saat aydınlık, 4saat karanlık) etüv de bekletilip çimlenme testi için petrilere aktarılmıştır (Fanan ve Novembre, 2007; Nascimento, 2005; Nascimento ve Lima, 2008; Trigo ve Trigo, 1999).

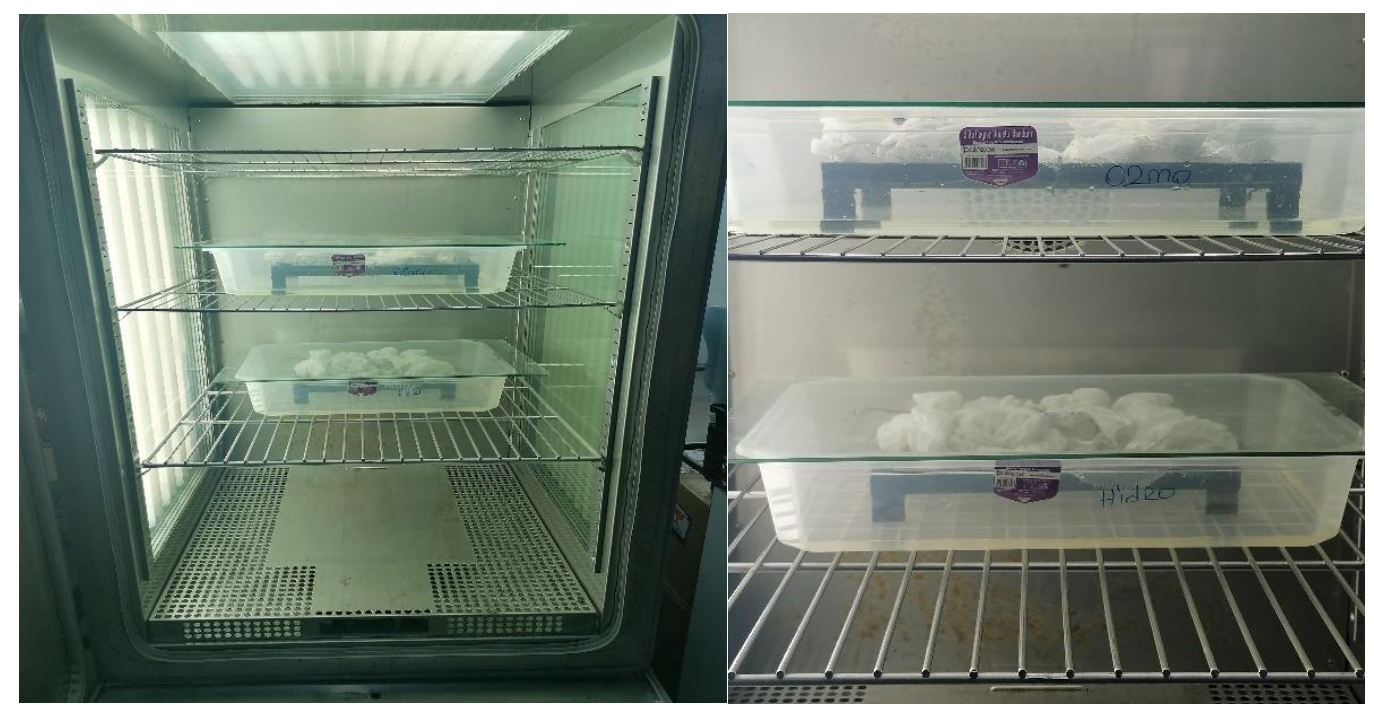

Şekil 2. Bitki büyütme dolabında (Nüve GC 400 ) osmo ve hidropriming uygulamalarının yapılışı 


\section{Termopriming:}

Farklı olgunluk dönemlerine göre keselenen tohumlar, $50^{\circ} \mathrm{C}^{\prime}$ de 2 farklı sürede (15 ve 30 dakika) su banyosunda bekletilmiştir. Çıkarılan tohumlar kurutma kağıtlarında fazla nemi alındıktan sonra çimlenme testi için petrilere aktarılmıştır.

\section{2. İstatistiksel Analiz}

Çalışma tesadüf parselleri deneme desenine göre yürütülmüştür. Laboratuvar testleri sonuçlarının istatistiksel önemi ve ortalamalar arasındaki farklar Duncan'ın çoklu ve tekli testleri kullanılarak $\mathrm{p} \leq 0.05$ düzeyinde değerlendirilmiştir. İstatistiksel analizde SPSS paket programı kullanılmıştır.

\section{Araştırma Bulguları ve Tartışma}

Kemer 27 çeşidinin tohum canlılık değerleri (toplam çimlenme, normal çimlenme, ortalama çimlenme zamanı, sürgün uzunluğu, kök uzunluğu, nem miktarı) bakımından ortalamalar arasındaki farkl11ıklar istatistiksel olarak çok önemli ( $\mathrm{p}<0.01)$ bulunmuştur (Tablo 1).

Tablo 1. Kemer 27 çeşidine ait varyans analiz tablosu

\begin{tabular}{ccccc}
\hline & Varyans & Serbestlik derecesi 1 & Serbestlik derecesi 2 & Önem derecesi \\
\hline TÇ & 2,717 & 41 & 84 &, 000 \\
\hline NÇ & 2,702 & 41 & 84 &, 000 \\
\hline OÇZ & 2,881 & 41 & 84 &, 000 \\
\hline SU & 5,029 & 41 & 84 &, 000 \\
\hline KU & 3,901 & 41 & 84 &, 000 \\
\hline NEM & 2,057 & 41 & 84 &, 003 \\
\hline
\end{tabular}

Denemelerde tohum canlılığının ele alındığı; priming, hasat zamanı (gün) ve priming $\mathrm{x}$ hasat zamanı interaksiyonu konularına bağlı olarak belirlenen parametrelerin istatistiksel olarak anlamlılık düzeyi tablo 2'de verilmiştir. Özellikle hasat zamanı sonuçlarının ortalamaları arasındaki farklılıklar $(\mathrm{p}<0.01)$ istatistiksel açıdan önemli bulunmuştur. Tam gelişmemiş tohum oranı dışındaki tüm özelliklerde hasat zamanları arası farklılığın \%1 olasılık düzeyinde önemli olduğu 
Çelik, Y., Kenanoğlu, B.B., Uluslararası Doğu Anadolu Fen Mühendislik ve Tasarım Dergisi / International Journal of Eastern Anatolia Science Engineering and Design (IJEASED)

(2020) 2(2):348-369

görülmektedir (Tablo 2). Çeşit x olgunlaşma dönemi (hasat gün) interaksiyonu toplam çimlenme, normal çimlenme ve nem sonuçları \%1 olasılık düzeyinde önemli bulunmuştur. Toplam ve normal çimlenme sonuçlarına göre; istatistiksel olarak tam gelişmemiş tohumlar (50 ve 55. gün hasatları) aynı grupta iken diğer olgunluk zamanları farklı gruplarda yer almıştır. Ortalama çimlenme zamanlarının sonuçlarında ise 50 ve 55. gün hasatları ayrı, diğer hasat zamanları ise aynı grup oluşturarak istatistiksel olarak iki gruba ayrılmıştır. Nem miktarları ile kök ve sürgün uzunlukları sonuçlarında ise ham tohum grubu (50.gün) diğer hasat zamanlarından ayrı grup olmuştur. Çalışmamızda toplam ve normal çimlenme sonuçlarına göre; istatistiksel olarak 15-35 ${ }^{\circ} \mathrm{C}$ 'de yapılan OP ve HP uygulamalarına tabi tutulan tohumlar aynı grupta yer almıştır. Sürgün uzunlukları sonuçlarında ise istatistiksel olarak kontrol, $50{ }^{\circ} \mathrm{C}$ 'de 30 dakikada yapılan TP ve 15-35 ${ }^{\circ} \mathrm{C}$ 'de yapılan HP uygulamalarının tohumları aynı grupta yer almıştır.

Tablo 2. İncelenen parametreler ait varyans analiz tablosu

\begin{tabular}{|c|c|c|c|c|}
\hline Varyasyon kaynağ 1 & Bağımlı değişkenler & Varyasyon & Kareler ortalamas 1 & Önem derecesi \\
\hline \multirow{6}{*}{ Priming } & TÇ & 6 & 1260,656 & ,000 \\
\hline & NÇ & 6 & 1734,550 &, 000 \\
\hline & OÇZ & 6 & 12,678 & ,006 \\
\hline & $\mathrm{SU}$ & 6 & 251,998 &, 102 \\
\hline & KU & 6 & 104,356 &, 005 \\
\hline & NEM & 6 & 4384,908 &, 000 \\
\hline \multirow{6}{*}{ Hasat gün } & TÇ & 5 & 16296,356 &, 000 \\
\hline & NÇ & 5 & 13920,337 & ,000 \\
\hline & OÇZ & 5 & 86,442 &, 000 \\
\hline & SU & 5 & 2121,137 &, 000 \\
\hline & $\mathrm{KU}$ & 5 & 302,630 & ,000 \\
\hline & NEM & 5 & 98,817 &, 000 \\
\hline \multirow{6}{*}{ Hasat gün * priming } & $\mathrm{TÇ}$ & 30 & 407,170 &, 000 \\
\hline & $\mathrm{NÇ}$ & 30 & 483,122 &, 000 \\
\hline & OÇZ & 30 & 4,727 & ,240 \\
\hline & SU & 30 & 110,126 &, 750 \\
\hline & $\mathrm{KU}$ & 30 & 19,414 & ,928 \\
\hline & NEM & 30 & 50,602 &, 000 \\
\hline
\end{tabular}


Tablo 2'de görüldüğü gibi, incelenen tüm özelliklerde farklı olgunlaşma dönemlerinin etkisi $\% 1$ olasılık düzeyinde önemli bulunmuştur. $\mathrm{Bu}$ sonuçlar, literatürde yer alan farklı priming uygulamaları ile benzerlik göstererek, çimlenme oranının arttığını destekler niteliktedir (Demir ve Okçu 2004, Venkatasubramanian ve Umarani 2007). Sebze türlerinin arasında patlıcan tohumları yavaş bir çimlenme süreci göstermektedirler (Demir 2003). ISTA kurallarına göre 14 günlük çimlenme periyodu önerilse de yapılan birçok çalışma sonrası elde edilen gözlemler bu sürenin uzatılması ile çimlenmenin devam edebileceği görülmüştür (Anonymus, 2017). Çimlenme periyodundaki yavaşlığın farklı nedenleri olsa da kısmen tohum dormansisinin bunda etkili olabileceği öngörülmektedir (Yogeesha ve ark., 2006). Bu durum kısmi dormansi olarak adlandırmaktadır. Bu dormansinin varlığı çimlenmeyi yavaşlatarak sürecin uzamasına ve kademeli çimlenmeye neden olmaktadır. Çalışmamızda, 50. ve 55. gün hasatlarına ait tohumlarda ortalama çimlenme zamanı 2-6 gün arası iken, 70. ve 90. gün hasatlarda ise 5-7 gün olarak belirlenmiştir. Genel olarak uygulamaların etkisi incelendiğinde ise; ham tohumlarda (50 ve 55. gün) OP 15 uygulaması, 60., 70. ve 80. gün hasat gruplarında HP 35 uygulaması sonucu çimlenme süresi en uzun olmuştur. Ancak 90. gün hasadının tohumlarında uygulanan OP 15-35 ve HP 15-35 sonucu ortalama çimlenme süresi benzerlik göstererek 7 günde tamamlanmıştır. Çimlenme sürecindeki değişkenlik fide kalitesini de olumsuz etkilemektedir. Özellikle bir heterojen gelişim ile popülasyon içinde farklı boyutlarda fideler oluşmaktadır (Demir ve ark., 2008). Tohum üretimi için patlıcan meyvesi normalde tam olgunlukta hasat edilir, bu da çeşide, iklime ve yetiştirme koşullarına bağlı olarak antesis döneminden yaklaşık 50-60 gün sonraya denk geldiği bildirilmiştir (Demir, 2002; Rashid, 2000; Yogeesha, 2008). 


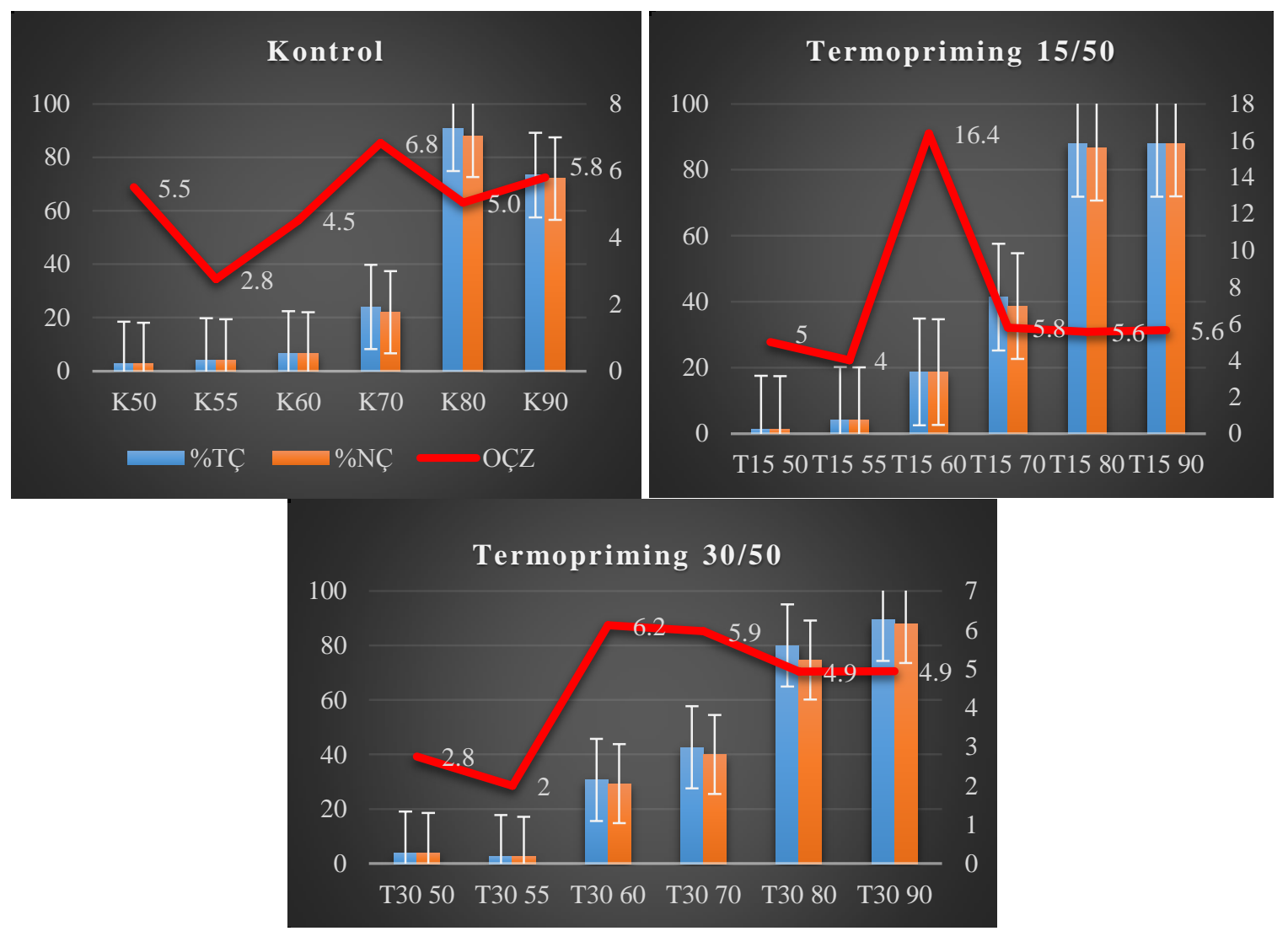

Şekil 3. Kemer 27 çeşidinin farklı olgunluktaki tohumlarında kontrol ve TP $\left(50^{\circ} \mathrm{C}, 15\right.$-30 dakika) uygulamaları sonrası toplam (TÇ) ve normal (NÇ) çimlenme oranları (\%) ile ortalama çimlenme zamanları (OÇZ, gün)

Kontrol ve termopriming uygulanmış grupların çimlenme sonuçları değerlendirildiğinde; çiçeklenmeden sonraki 60, 70 ve 90. gün hasatlarına ait tohumların çimlenme performansında termopriming ile artış sağlandığı görülmüştür. Kemer çeşidinin toplam çimlenme sonucunda, 90. gün tohum hasadında $50^{\circ} \mathrm{C}$ 'de 30 dakikalık termopriming ile artış belirlenmiştir (Şekil 3). Duran (2016) yaptığı çalışmada da patlıcan türünde tohum gücü ve fide kalitesi, yapılan termopriming (TP) ve kurutma uygulamalarının etkileri ile incelemiştir. Kemer 27, Pala 49 ve Topan 374 çeşidi patlıcan tohumlarına farklı sicaklık $\left(40,45\right.$ ve $\left.50^{\circ} \mathrm{C}\right)$ ve sürelerde $(5,10,15,20,25$ ve $30 \mathrm{dk}) \mathrm{TP}$ uygulanmıştır. Patlıcan tohumlarının TP ve kurutma uygulamalarına olan tepkileri canlılık (normal çimlenme oranı) ve farklı güç parametreleri değerlendirilmiştir. Bu çalışmadan elde edilen sonuçlar ile TP ve kurutma uygulamalarının tohum canlılık ve gücünde artış sağlamasından dolayı tohum ve fide endüstrisine tavsiye edilebilir nitelikte olduğu sonucu ortaya konulmuştur. 


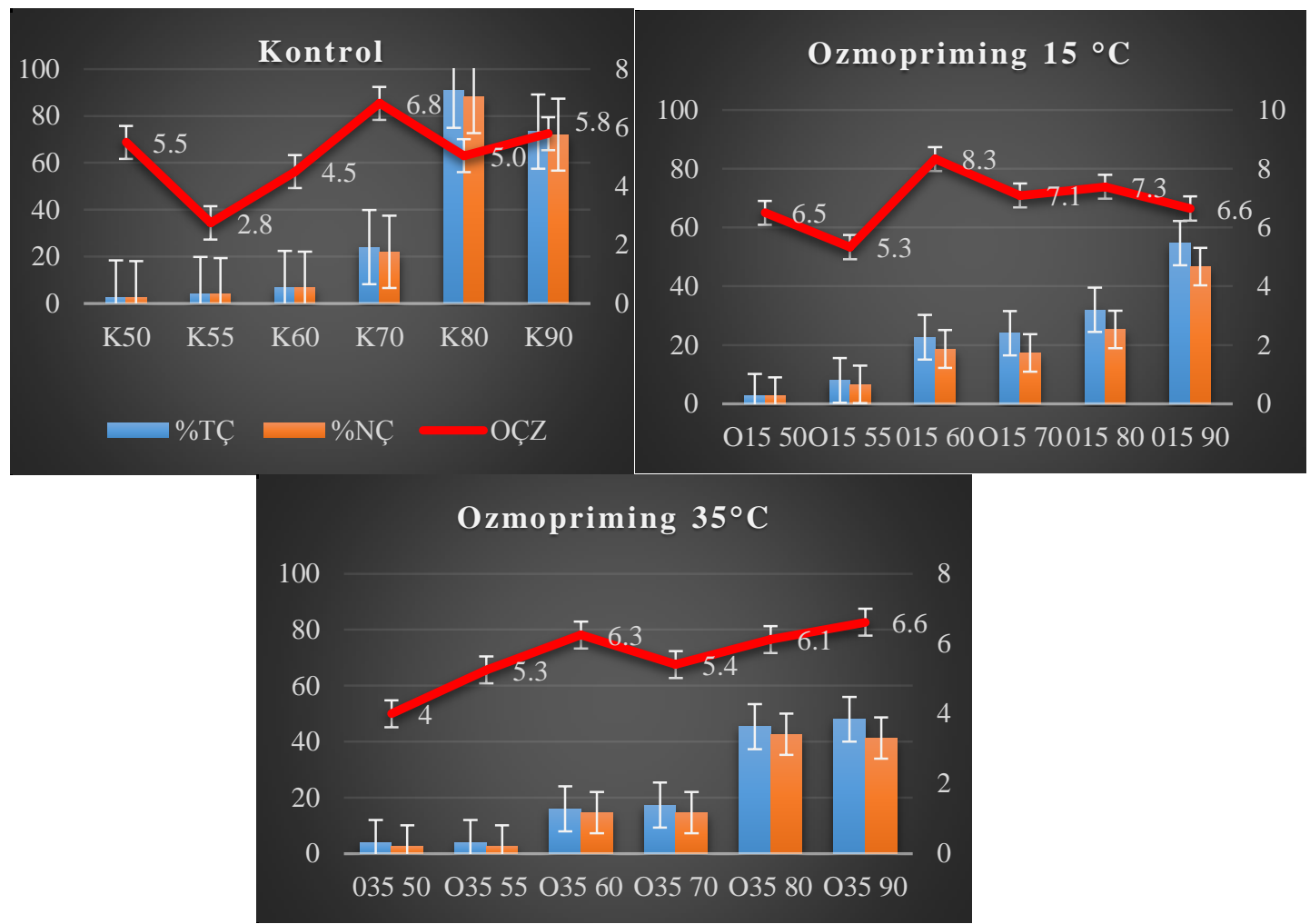

Şekil 4. Kemer 27 çeşidinin farklı olgunluktaki tohumlarında kontrol ve OP $\left(15\right.$ ve $\left.35^{\circ} \mathrm{C}\right)$ uygulamaları sonrası toplam (TÇ) ve normal (NÇ) çimlenme oranları (\%) ile ortalama çimlenme zamanları (OÇZ, gün)

Kontrol ve ozmopriming uygulanmış grupların çimlenme sonuçları değerlendirildiğinde; özellikle tam olgunluğa ulaşamayan çiçeklenmeden sonraki 60 ve 70. gün hasatlarına ait tohumların çimlenme (TÇ, NÇ) performansında ozmopriming ile artış sağlandığı görülmüştür. Ancak bu tohumların canlılığı yinede ticari olarak satılabilecek seviyeye ulaşmamıştır. Kemer çeşidinin tohum çimlenme parametrelerinde en yüksek toplam çimlenme sonucu 90. gün tohum hasadında 15 ${ }^{0} \mathrm{C}$ 'de uygulanan ozmopriming ile belirlenmiştir (Şekil 4). Brezilya koşullarında, patlıcan tohumlarının fizyolojik olgunluğu ile ilgili yapılan bir çalışmada ise, kaliteli tohumların antesisden sonraki 50. günde hasat edilen meyvelerden alındığı belirlenmiş ve daha yüksek çimlenme yüzdesi elde etmek için tohumların antesisten 86 gün sonra toplanması gerektiği vurgulanmıştır. Ayrıca hasat sonrası bekletmenin çimlenme yüzdesini etkilemediği gözlemlenmiştir (Martins ve ark., 2012). Yine benzer bir çalışmada ise, antesisden 70 gün sonra toplanan tohumlarda, embriyonun su kapsamını arttırmak için yeterli düzeyde ozmotik potansiyel oluşturularak birincil kökün daha önceki hasatlardan iyi çıkış gösterdiği izlenmiştir (Hegarty, 1978). Bu sonuçlar ile lahana ve kolza tohumlarında Still ve Bradford (1998), kavunda Welbaum ve Bradford (1990), patlican tohumlarında Demir ve diğerleri (2003) de olgunlaşmamış tohumlara dışarıdan uygulanan ozmotik 
Çelik, Y., Kenanoğlu, B.B., Uluslararası Doğu Anadolu Fen Mühendislik ve Tasarım Dergisi / International Journal of Eastern Anatolia Science Engineering and Design (IJEASED)

(2020) 2(2):348-369

potansiyel ve tuz streslerine olgun dönem tohumlarına göre daha duyarlı olduklarını belirlenmişlerdir. Tuzların hem ozmotik hem de toksik etkileri çimlenme performansını engellemektedir (Allen ve ark.,1986). Demir ve arkadaşları (2008), farklı olgunluktaki biber tohumları ile yaptıkları çalışmada; aynı hasat dönemini ve konsantrasyonlardaki sonuçları PEG ile karşılaştırıldığında $\mathrm{NaCl}$ uygulaması ile çimlenme yüzdeleri daha yüksek olmuş ve PEG' in çimlenme üzerindeki olumsuz etkisinin spesifik iyon birikiminden çok ozmotik etkiden olabileceğini ortaya koymuşlardır. Mehra ve diğerleri (2003), PEG moleküllerinin tohuma girmediğini ve bu nedenle tohumun ve çevresinin su potansiyeli dengeye geldiğinde tohumun emilmeye devam etmeyeceğini öne sürmüştür. Bu gibi sebeplerden ötürü çalışmamızda uygulanan ozmopriming sonucu çimlenme performansı kontrolden daha kötü olmuştur.
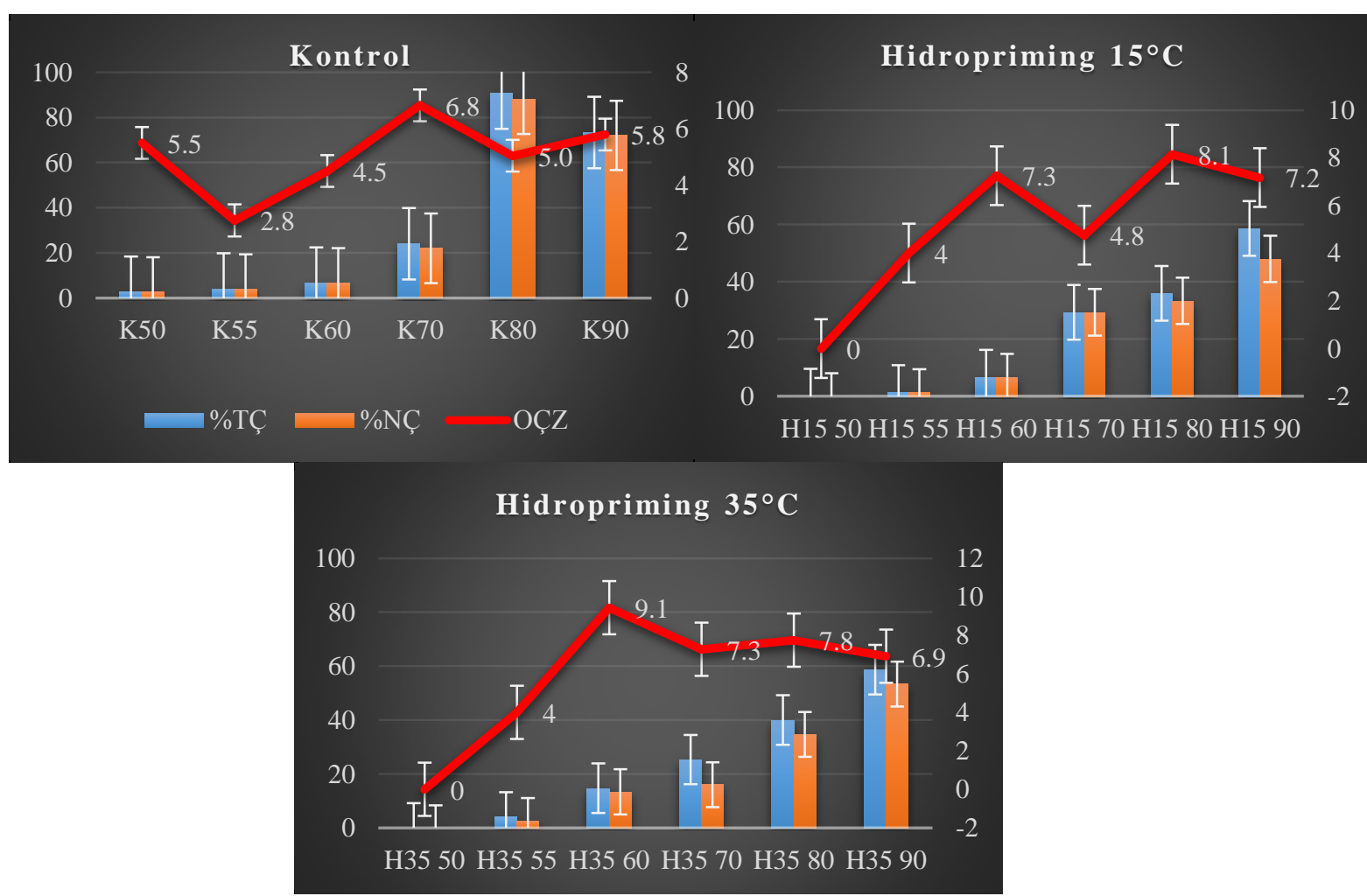

Şekil 5. Kemer 27 çeşidinin farklı olgunluktaki tohumlarında kontrol ve HP $\left(15\right.$ ve $\left.35^{\circ} \mathrm{C}\right)$ uygulamaları sonrası toplam $(\mathrm{TÇ})$ ve normal $(\mathrm{NÇ)}$ çimlenme oranları (\%) ile ortalama çimlenme zamanları (OÇZ, gün)

Kontrol ve hidropriming uygulanmış grupların çimlenme sonuçları değerlendirildiğinde; özellikle tam olgunluğa ulaşamayan çiçeklenmeden sonraki 60. ve 70. gün hasatlarına ait tohumların çimlenme (TÇ, NÇ) performansında hidropriming ile artış sağlandığı görülmüştür (Şekil 5). Yapılan bir çalışmada; patlıcan meyvelerini tozlaşmadan 70 gün sonra hasat etmek yüksek 
fizyolojik kalitede tohum fermantasyonu için ideal bulunmuştur. Ayrıca meyvelerin hasat sonrası depolama süresi, patlıcan tohumlarının fizyolojik kalitesini değiştirmemiştir (Martins ve ark., 2012). Oksijence zenginleştirilen saf suda $20^{\circ} \mathrm{C}$ sıcaklıkta farklı sürelerde tutulan Pala 49 çeşidi patlıcan tohumları ile yapılan araştırmada; hidropriming uygulamaları ile tohumların ulaştıkları nem kapsamları hesaplanmış ve iki kısma ayrılmışlardır. Tohumların bir kısmına yüzeysel kurutma yapılmış, diğer yarısı ise orijinal nem kapsamlarına gelinceye kadar kurutulmuştur. Patlıcan tohumlarının hidropriming ve kurutma uygulamalarına göre normal çimlenme oranı, ortalama çimlenme süresi, çimlenme indeksi, fide güç indeksi ve fide kuru ağırlıkları gibi parametreler değerlendirilmiştir. Sonuç olarak, hidropriming grubu kontrol grubuna göre tohum canlılığı ve gücünde artış belirlenmiştir (Sivritepe ve Teoman, 2014). Hidrasyonun başlangıcında, yüksek matris potansiyeli çimlenmenin gecikmesi veya çimlenmeyi normalde önleyen veya geciktiren çözeltilerden su emilmesine neden olabileceği belirtilmiştir (Marshall ve Naylor, 1985).

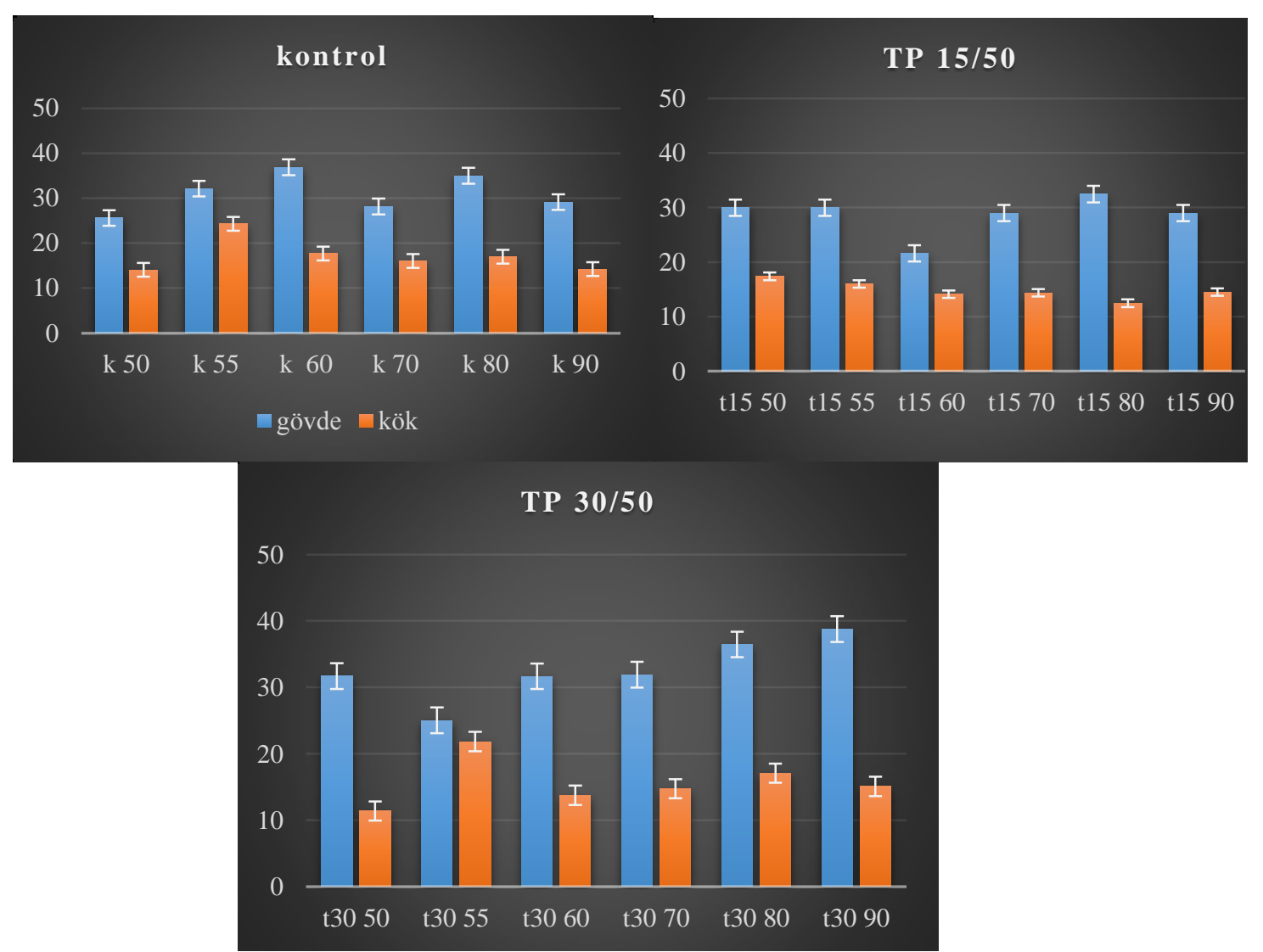

Şekil 6. Kemer 27 çeşidinin farklı olgunluktaki tohumlarında kontrol ve TP $\left(50^{\circ} \mathrm{C}, 15\right.$-30 dakika) uygulamaları sonrası kök ve gövde uzunlukları $(\mathrm{mm})$

Kök ve sürgün uzunlukları sonuçları irdelendiğinde; termopriming uygulaması ile değişken etkiler belirlenmiştir. Özellikle $50^{\circ} \mathrm{C}$ de 30 dakika uygulanan TP ile kök uzunlukları 55, 80 ve 90. 
Çelik, Y., Kenanoğlu, B.B., Uluslararası Doğu Anadolu Fen Mühendislik ve Tasarım Dergisi / International Journal of Eastern Anatolia Science Engineering and Design (IJEASED)

(2020) 2(2):348-369

gün hasatlarında kontrole göre daha uzun olurken, sürgün uzunlukları ise 55 ve 60 . gün hariç diğer hasatlarda kontroldeki değerlerin arttı̆̆ı görülmüştür (Şekil 6). Benzer sonuçlar aynı familya üyesi olan domates tohumları ile yapılan çalışmada da belirlenmiştir. 50,60 ve $70^{\circ} \mathrm{C}^{\prime}$ lerde 15,2 ve $1-2 \mathrm{dk}$ boyunca su emdirilen tohumlar ekimden sonraki 30 günde kontrolden \%20 daha uzun olmuştur (Klein ve Hebbe, 1994).

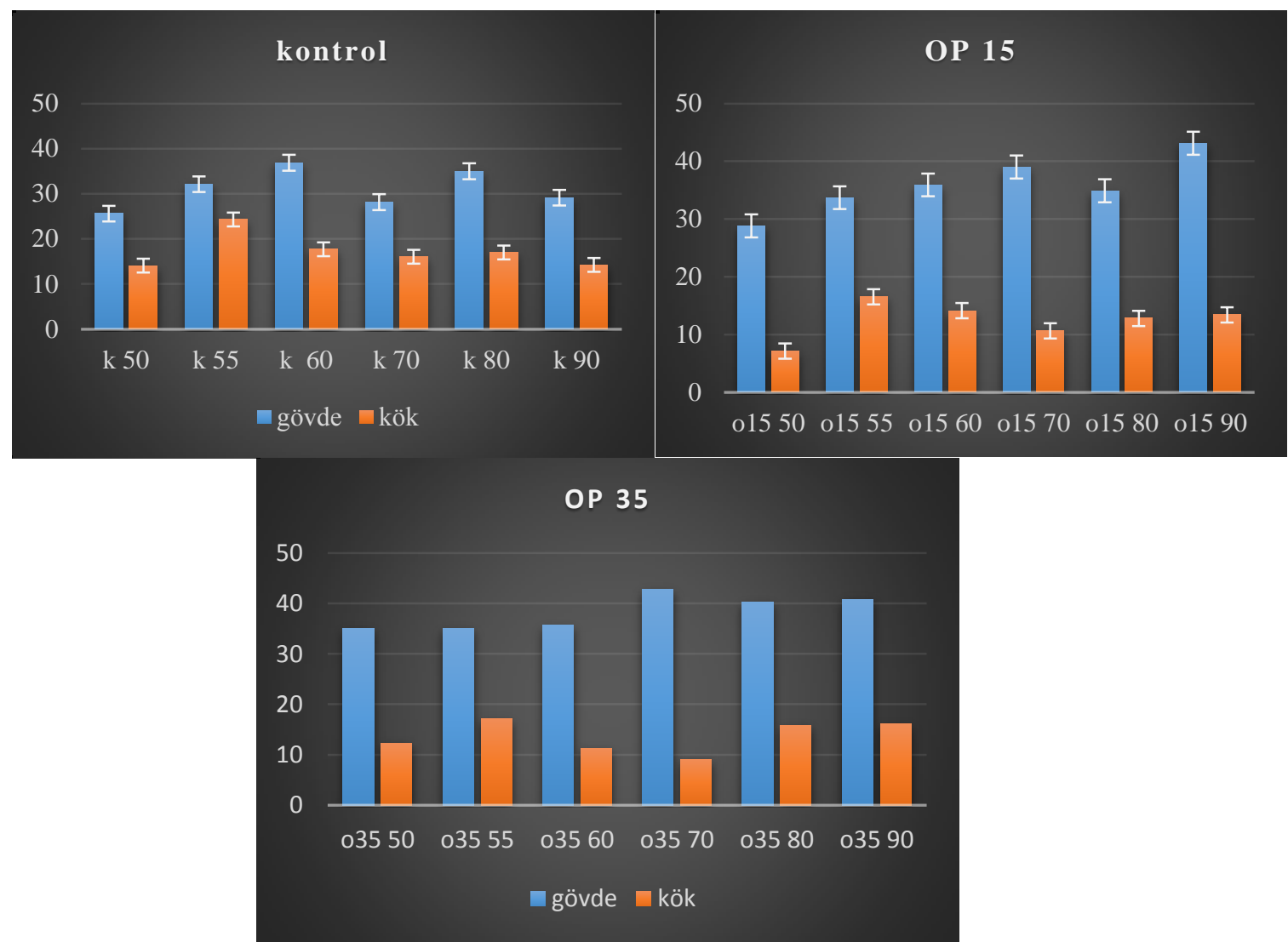

Şekil 7. Kemer 27 çeşidinin farklı olgunluktaki tohumlarında kontrol ve OP $\left(15\right.$ ve $\left.35^{\circ} \mathrm{C}\right)$ uygulamaları sonrası kök ve gövde uzunlukları (mm)

Kök ve sürgün uzunlukları sonuçlarında ozmopriming uygulamasının etkisi ele alındığında; kök uzunluklarının kontrol grubunda daha uzun olduğu, sürgün uzunluklarının ise kontrole (25-36 $\mathrm{mm})$ grubuna göre OP uygulamasından $(28-55 \mathrm{~mm}$ ) daha olumlu etkilendiği belirlenmiştir (Şekil 7). Daha önceki çalışmalar, çimlenme parametrelerinin, düşük konsantrasyonlu tuz çözeltilerinde yüksek konsantrasyonlardan daha fazla arttığını göstermiştir. Ayrıca priming işleminin başarısının, bitki türü, priming maddesinin su potansiyeli, priming süresi, sıcaklık, tohum gücü ve dehidrasyon ile priming yapılan tohumun depo koşulları gibi faktörlerin kombinasyonundan etkilendiğini göstermiştir (Moradidezfuli ve ark., 2008). Ancak Luna ve Moreno'ya (2009) göre, bu faktörlere duyarlılık türe göre değişir. PEG çözeltisi oksijen difüzyonunu kısıtlayabilir ve tohum solunumu 
engellenebilir (Nascimento ve Costa, 2009) hatta ikincil bir dormansi hali başlatılabilir (Trigo ve ark.,1999) ayrıca etkilenen parametreler tekdüzelik ve çimlenme yüzdesidir.

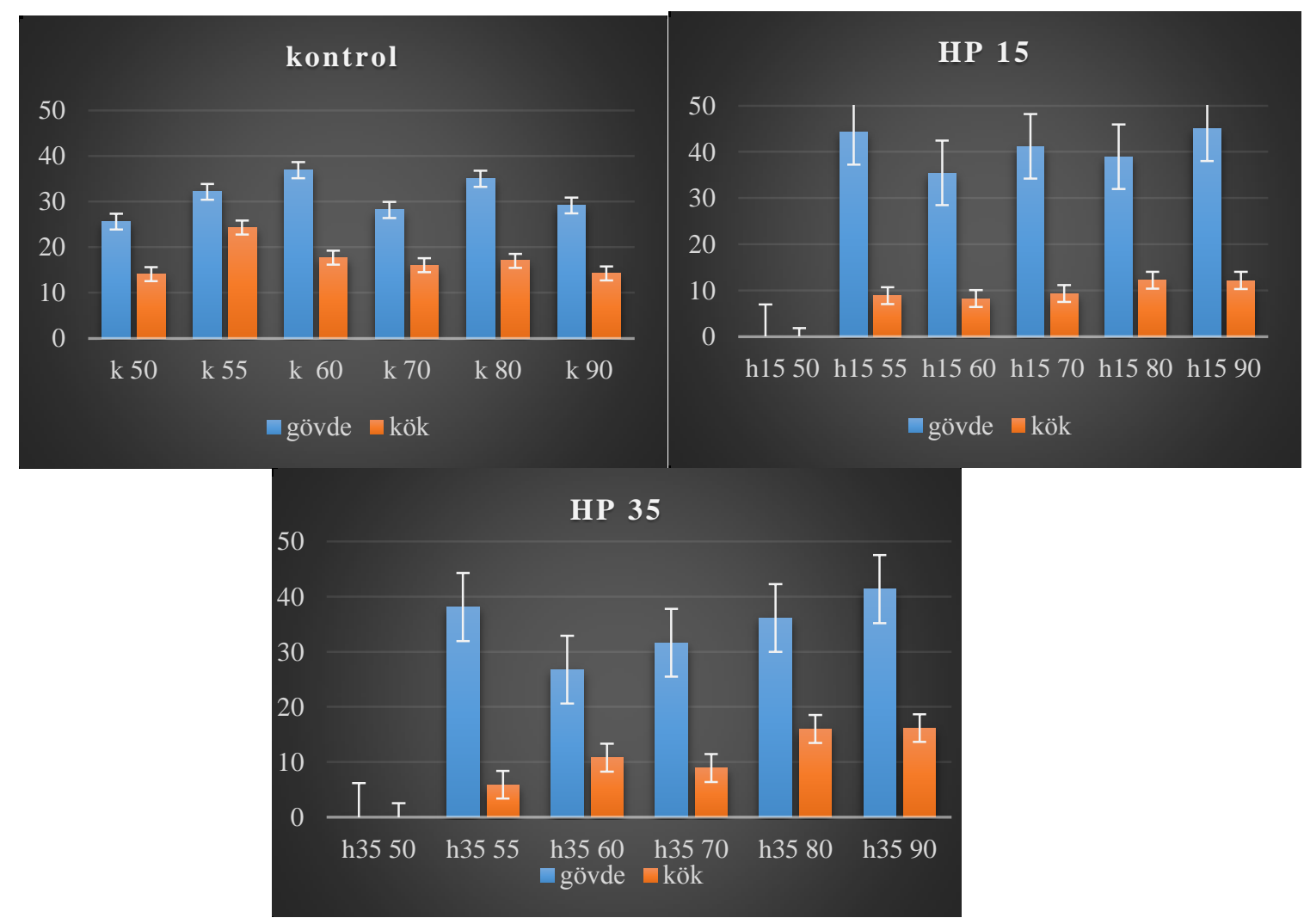

Şekil 8. Kemer 27 çeşidinin farklı olgunluktaki tohumlarında kontrol ve HP $\left(15\right.$ ve $\left.35^{\circ} \mathrm{C}\right)$ uygulamaları sonrası kök ve gövde uzunlukları (mm)

Kök ve sürgün uzunlukları sonuçlarında hidropriming uygulaması ile de özellikle 90. gün hasatlarının tohumlarında sürgün uzunlukları kontrol grubundan göre daha uzun olmuştur (Şekil 8). Venkatasubramanian ve Umarani (2007) yaptıkları çalışma ile domates, patlıcan ve biberde homojen ve hızlı bir çimlenme için osmopriming (PEG 1000) ve halopriming $\left(\mathrm{KNO}_{3}\right.$ ve $\left.\mathrm{NaCl}\right)$ işlemlerini değerlendirmişlerdir. $\mathrm{Bu}$ yöntemler arasında, patlıcan, biber ve domates için hidropriming (48 saat), tohumun canlılığını artırabilen en iyi yöntem olarak belirlenmiştir. 


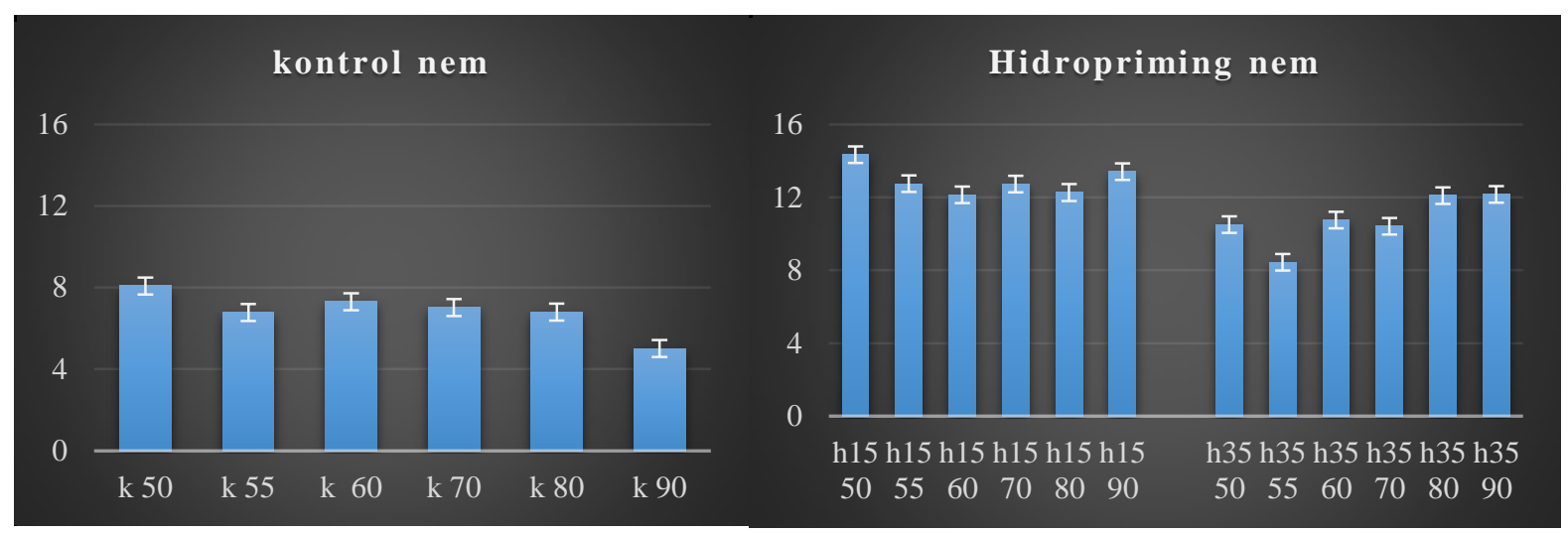

Şekil 9. Kemer 27 çeşidinin farklı olgunluktaki tohumlarında kontrol ve HP $\left(15\right.$ ve $\left.35^{\circ} \mathrm{C}\right)$ uygulamaları sonrası nem miktarlarındaki değişim (\%100)

Kontrol ve priming gruplarındaki nem değişimlerinin sonuçları, yapılan tüm priming uygulamaları ile tohumların nem düzeylerinde belirgin artışlar olmuştur. Hidropriming sonrası tohumların nemleri; 50. gün hasatlarında $\% 4,55$. günde $\% 3,60,70$ ve 80 .günde $\% 4,90$. günde $\% 8$ artmıştır. Ozmopriming ile bu değerler 50. günde \%3, 55. günde \%5, 60, 70 ve 80. günde \%6, 90. günde ise $\% 7$ oranında değişmiştir. Termopriming gruplarında ise en belirgin değişim elde edilmiştir. 50. günde $\% 45,55$. günde $\% 41,60$. günde $\% 39,70$. günde $\% 31,80$. günde $\% 28.5,90$. günde ise \%27.5 oranında değişmiştir (Şekil 9,10).

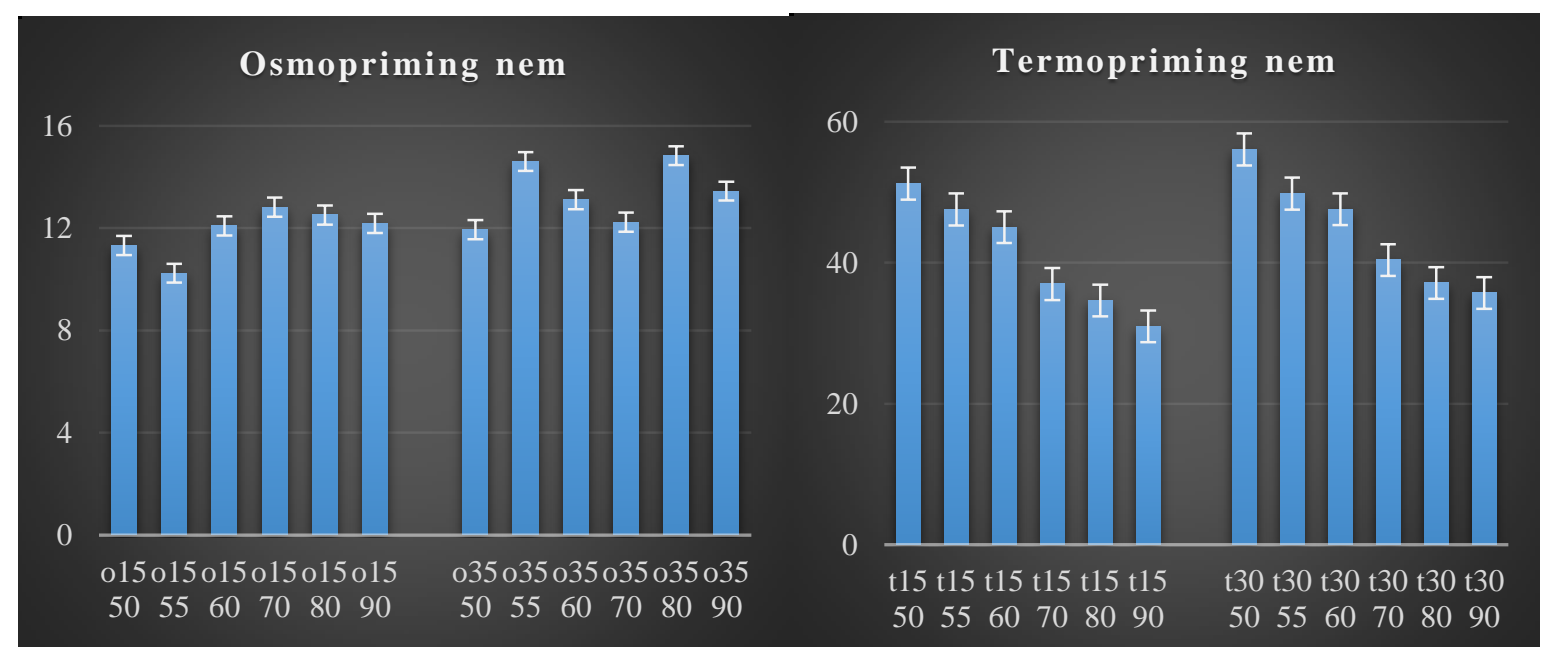

Şekil 10. Kemer 27 çeşidinin farklı olgunluktaki tohumlarında OP $\left(15\right.$ ve $\left.35^{\circ} \mathrm{C}\right)$ ve TP $\left(50^{\circ} \mathrm{C}, 15-30\right.$ dakika $)$ uygulamaları sonrası nem miktarlarındaki değişim $(\% 100)$ 


\section{Sonuçlar}

Meyve gelişim ve olgunlaşma sürecinde tohumun gelişimi; genetik, fizyolojik ve çevre koşullarını içeren birçok faktörden etkilenmektedir. Bu nedenle aynı çevre koşullarında yetiştirilen bitkilerde tohum gelişim dönemleri farklı olabilmektedir. Gelişme sırasında maksimum tohum kalitesine ulaşılması tohum ve meyve özellikleriyle ilişkili olup, ideal hasat süresini tanımlamak için önemlidir. Bu çalışmada, Kemer 27 patlıcan tohumlarında çimlenmenin başlangıç aşamalarında kalite ve performansı arttırmak amacıyla yapılan HP, OP ve TP uygulamaları ile çeşitli denemeler gerçekleştirilmiştir. Denemelerden elde edilen sonuçlar canlılık (TÇ, NÇ, OÇZ, kök-sürgün uzunluğu) bazında değerlendirilmiştir. Kemer çeşidinin tohum çimlenme parametrelerinde en yüksek çimlenme sonuçları 80. gün tohum hasatlarında elde edilmiştir. Bu sonucu 90. gün tohum hasatlarında $50^{\circ} \mathrm{C}$ 'de $15-30$ dakikalık termopriming (\%89), 15-35 ${ }^{0} \mathrm{C}$ 'de uygulanan hidropriming (\%58) ve $15{ }^{\circ} \mathrm{C}$ 'de uygulanan ozmopriming (\%55) gruplarında belirlenmiştir (Şekil 3,4,5). Özellikle 60-70. gün hasatlarında termopriming ile çimlenme değerleri \%10-20 oranında artmıştır. Kök ve sürgün uzunlukları sonuçları açısından, $50^{\circ} \mathrm{C}$ de 30 dakika uygulanan TP ile kök uzunlukları 55, 80 ve 90. gün hasatlarında kontrole göre daha uzun olurken, sürgün uzunlukları ise 55 ve 60. gün hariç diğer hasatlarda kontroldeki değerlere göre arttı̆̆1 belirlenmiştir (Şekil 6). Kök ve sürgün uzunlukları hidropriming uygulaması ile de özellikle 90. gün hasatlarının tohumlarında sürgün uzunlukları kontrol grubundan daha uzun olmuştur (Şekil 8). Çimlenme oranının \%75-80 arasında olması bir tohumluğun ticari olarak tohumluk özelliği taşıması için gerekli orandır. Yapılan priming çalışması ile canlılık seviyelerinin standardı sağlanmaktadır. Yapılacak çalışmalarda, daha fazla olgunluk seviyelerine sahip tohum partilerinde değişken süre ve konsantrasyonlarda priming uygulamaları ile daha belirgin sonuçlara varılabilir.

\section{Yazarların Katkısı}

Çalışmada her iki yazar da eşit oranda katkı sunmuştur.

\section{Çıkar Çatışması Beyanı}

Yazarlar arasında herhangi bir çıkar çatışması bulunmamaktadır.

\section{Araştırma ve Yayın Etiği Beyanı}

Yapılan çalışmada, araştırma ve yayın etiğine uyulmuştur. 
Çelik, Y., Kenanoğlu, B.B., Uluslararası Doğu Anadolu Fen Mühendislik ve Tasarım Dergisi / International Journal of Eastern Anatolia Science Engineering and Design (IJEASED)

(2020) 2(2):348-369

\section{Teșekkür}

Bu çalışma birinci yazarın ikinci yazar danışmanlığında hazırlandığı yüksek lisans tezinin bir bölümünden üretilmiştir.

\section{Kaynaklar}

Allen, S. G., Dobrenz, A. K., Bartels, P. G., (1986), Physiological response of salt-tolerance and nontolerant alfalfa to salinity during germination. Crop Science, 26, 1004-1008.

Anonymus. (2017). International Seed Testing Association. International rules for seed testing. Zurich, Switzerland.

Chen, N.C., (2001). Eggplant seed production. AVRDC International Cooperators' Guide. Asian Vegetable Research and Development Center, Shanhua, Taiwan, pp. 4.

Demir, İ., Ellis, R.H., (1992). Changes in seed quality during seed development and maturation in tomato. Seed Science Research, v.2, p.81-87.

Demir, İ., Mavi, K., Sermenli, T., Ozcoban, M., (2002). Seed development and maturation in aubergine (Solanum melongena L.), Gartenbauwissenschaft, 67: 148-154.

Demir, İ., (2003). Effect of controlled hydration treatment on quality of aubergine seeds following storage. Phyton, 43(2), 307-317.

Demir, İ., Mavi, K., Ozcoban, M., Okcu, G., (2003). Effect of salt stress on germination and seedling growth in serially harvested aubergine (Solanum melongena L.) seeds during development. Israel J. Plant Sci.,51, 125-131.

Demir, İ., Ermis, S., Mavi, K., Matthews, S., (2008). Mean germination time of pepper (Capsicum annuum L.) Seed lots predicts size and uniformity of seedlings in germination tests. Seed Science And Technology, 36(1), 21-30

Demır, İ., Okcu, G., (2004). Aerated Hydration Treatment For İmproved Germination And Seedling Growth İn Aubergine (Solanum melongena) And Pepper (Capsicum annuum), Ann. appl. Biol., 144:121-123.

Duran, U.T.,(2016).Patlıcan Tohumlarında TermoPrımıng Uygulamalarının Fide Kalitesi ve Performansı Üzerine Etkiler,Yüksek Lisans Tezi, Uludağ Üniversitesi Fen Bilimleri Enstitüsü,Bursa.

Elkoca, E., Haliloğlu, K., Eşitken, A., Ercişli, S.,(2006). Hydro and osmopriming improve chickpea germination, Acta Agriculturae Scandinavica Section B, Soil and Plant Science, 57(3): 193-200.

Fanan, S., Novembre, A.D.L.C., (2007). Condicionamento fisiológico de Sementes De Berinjela. Bragantia, V. 66, N. 4, P. 675-683.

FAO. Patlıcan üretim miktarı(2018),http://www.fao.org/faostat/en/\#data/QC, (Erişim Tarihi: 17.09.2020).

Hardegree, S.P., (1996). Optimization of seed priming treatments to increase low temperature germination rate, Journal of Range Management, 49: 87-92.

Hegarty, T W., (1978). The physiology of seed hydration and dehydration and relation between water stres and control of germination: A Review. Plant Cell And Environment, 1, 1001-1119.

Ibrahim, A.E., Roberts, E.H.,(1983). Viability of lettuce seeds. I. Survival in hermetic storage. Journal of Experimental Botany, 34: 620-630.

ISTA (1999): International Rules for Testing Seeds. Seed Sci. and Technol. 27: 155-175.

Karapanos, I., Mahmood, S., Thanopaulos, C.,(2008). Fruit set in solanaceous vegetable crops as affected by floral and environmental factors, The European Jaurnal of Plant Science And Biotechnology, 2, s85105

Klein, J.D., Hebbe, Y., (1994). Growth of tomato plants following short term high temperature seed priming with calcium chloride, Seed Science and Technology, 22: 223-230.

Luna, B., Moreno, J.M., (2009). Light and nitrate effects on seed germination of mediterranean plant species of several functional groups. Plant Ecology, V.203, N.1, P.123-135

Martins, D.,Vilela, F., Guimaraes, R., Gomes, L., Silva, P., (2012). Physiological Maturity of Eggplants Seeds, Revista Brasileira de sementes, 34(4), s534-540. 
Marshall, A. H., Naylor, R. E. L . (1985). Ryegrass seedwater relationships. Seed Science and Technology, $13,829-845$

McDonald, M.B., Black M., (Eds) Bewley J.D.,(2000). Seed technology and its biological basis. Sheffield, UK; Sheffield AcademicPress.

Mehra, V., Tripathi, J., Powell, A.A., (2003), Aerated hydration treatment improves the response of Brassica juncea and Barassica campestris seeds to stres during germination. Seed Sci. Technol, 31, 57- 70.

Min, T.G., Seo, B.M.,(1999). Optimum conditions for tobacco seed priming by PEG 6000, Korean Journal of Crop Science, 44(3): 263-266.

Mexal, J., Fisher, J.T., Osteryoung, J., Reid, C.P.,(1975). Oxygen availability in olyethyleneglycol solutions and its implications in plant-water relations, Plant Physiology, 55: 20-24.

Moradidezfuli, P., Sharif-Zadeh, F., Janmohammadi, M., (2008). Influence Of Priming techniques On Seed germination behavior Of Maize in bredlines (Zea mays L.). Journal Of Agriculture and biological sciences. 3, 22-25.

Nascimento, W.M., (2005). Condicionamento osmótico De Sementes De Hortaliças visando A Germinação Em Condições De Temperaturas baixas. Horticultura brasileira, V.23, N.2, P.211-214.

Nascimento, W.M., Pereira, R.S. (2007). Preventing thermo-inhibition in carrot by seed priming. Seed Sci. \& Technol., 35, 504-507.

Nascimento, W.M., Costa, C.J., (2009). Condicionamento osmótico De Sementes De Hortaliças. Tecnologia De Sementes De Hortaliças, P.345-396.

Nascimento, W.M., Lima, L.B., (2008). Condicionamento osmótico De Sementes De Berinjela visando A Germinação sob temperaturas baixas. Revista brasileira De Sementes, V.30, N.2, P.224-227.

Parera C.A., Cantliffe D.J.,(1994). Pre-sowing seed priming, Horticultural Reviews, 16: 109-141.

Passam, H.C.,Baltas, C., Boyiatzoglou, A., Khah, E.M., (2001). Flower morphology and number of aubergine (Solanum melongena L.) in relation to fruit load and auxin application. Scientia Horticulturae, 89: 309-316.

Passam, H.C., Theodoropoulou, S., Karanissa, T., Karapanos, I.C., (2010). Influence of harvest time and after-ripening on the seed quality of eggplant. Scientia Horticulturae, 125: 518-520.

Rashid, M.A., Singh, D.P., (2000). A manual on vegetable seed production in Bangladesh. Bangladesh; AVRDC-USAID-Bangladesh Project, Horticulture Research Centre, Bangladesh Agricultural Research Institute Joydebpur, pp. 119.

Sani, B., Jodaeian, V., (2015). The Role of Thermo Priming on Improving Seedling Production Technology (Ispt) in Soybean [Glycine max (L.) Merrill] Seeds. International Journal of Biological, Biomolecular, Agricultural, Food and Biotechnological Engineering Vol:9, No:7.

Saxena O.P., Singh G.,(1987). Osmotic priming studies in some vegatable seeds. Acta Horticulturae. 215:201-207.

Sharmaa, A.D., Rathore S.V.S., Srinivasana, K., Tyagi R.K.,(2013). Comparison of various seed priming methods for seed germination, seedling vigour and fruit yield in okra (Abelmoschus esculentus L. Moench), Scientia Horticulturae, 165: 75-81.

Sivritepe, H.Ö., Teoman, S.,(2014). Patlıcan tohumlarının fizyolojik olarak iyileştirilmesinde kullanılan farklı hidrasyon ve kurutma uygulamalarının karşılaştırması. 10. Sebze Tarımı Sempozyumu.Tekirdağ.

Sivritepe, H.Ö., Eriş, A., (2000). The effect of post-storage hydration treatments on viability and repair of genetic damage in peaseeds. ActaHort. 517: 143-149.

Sivritepe, H.Ö., (1999). Sebze tohumlarında kalite ve performansın arttırılması üzerine ozmotik koşullandırmanın etkileri. Türkiye 3. Ulusal Bahçe Bitkileri Kongresi (s. 525-529). Ankara.

Still, D. W., Bradford, K. J., (1998). Using hydrotime and ABA-times model to quantify seed quality of Brassicas during development. J. Amer. Soc. Hort. Sci,123(4), 692-699.

Tajbakhsh, M., Brown, P.H., Gracie, A.J., Spurr, C.J., Donovan, N., Clark, R.J.,(2004). Mitigation of stunted root abnormality in onion (Allium cepa L.) using seed priming treatments, Seed Science and Technology, 32: 683-692.

Trigo, M.F.O.O., Trigo, L.F.N., (1999). Effect of priming on germinationand on vigor of eggplant (Solanum melongena L.) Seeds. Revista brasileira De Sementes. 21, 107-113.

Trigo, M.F.O.O., Nedel, J.L., Trıgo, L.F.N., (1999). Condicionamento osmótico Em Sementes De Cebola: I. Efeitossobre A Germinação. Scientia Agricola, Piracicaba, V.56, N.4, P.1059-1067. 
Çelik, Y., Kenanoğlu, B.B., Uluslararası Doğu Anadolu Fen Mühendislik ve Tasarım Dergisi / International Journal of Eastern Anatolia Science Engineering and Design (IJEASED)

(2020) 2(2):348-369

TÜİK. Patlıcan üretim miktarl 2019,https://biruni.tuik.gov.tr/medas/?kn=92\&locale=tr, (Erişim Tarihi: 17.09.2020).

Venkatasubramanian, A., Umarani, R., (2007). Evaluation of seed priming methods to improve seed performance of tomato (Lycoperison esculentum), eggplant (Solanum melongena) and chilli (Capsicum annum), SeedSci. \& Technol,35, 487-493.

Vidigal, D., Dias, D., Dias, L., Finger, F. (2011). Changes in Seed Quality During Fruit Maturation of Sweet Pepper, Programa de Pós-Graduação em Fitotecnia,68(5), s535-539.

Yogeesha, H.S., Singh, T.H., Naik, L.B., (2008). Seed germination in relation to seed development in eggplant (Solanum melongena), IndianJournal of Agricultural Science, 78: 1010-1012.

Yogeesha, H.S., Upreti, K.K., Padmini, K., Bhanuprakash, K., Murti, G.S.R., (2006). Mechanism of seed dormancy in eggplant (Solanum melongena L.). Seed Science and Technology, 34(2), 319-325.

Ward, F.H., Powell, A.A.,(1983). Evidence for repair processes in onion seeds during storage at high seed moisture contents, Journal of Experimental Botany, 34: 277-282.

Welbaum, G. E., Tissaoui, T., Bradford, K. J., (1990), Water relations of seed development and germination in muskmelon (Cucumis melo L.) III. Sensitivity of germination to water potential and abscisic acid during development. PlantPhysiology, 92, 1029-1037. 